\title{
Mineralocorticoid-Induced Sodium Appetite and Renal Salt Retention: Evidence for Common Signaling and Effector Mechanisms
}

\author{
Yiling $\mathrm{Fu}^{\mathrm{a}, \mathrm{c}}$ Volker Vallon ${ }^{\mathrm{a}-\mathrm{c}}$ \\ Departments of a Medicine and b Pharmacology, University of California San Diego, La Jolla, Calif., and \\ 'Department of Veterans Affairs, San Diego Healthcare System, San Diego, Calif., USA
}

\section{Key Words}

Aldosterone - Salt intake · Hypertension - Kidney · Brain .

Tongue $\cdot$ Mineralocorticoid receptor $\cdot \mathrm{ENaC} \cdot$ Salt appetite .

Angiotensin II · NEDD4-2 · SGK1 · Sodium reabsorption

\begin{abstract}
An increase in renal sodium chloride (salt) retention and an increase in sodium appetite are the body's responses to salt restriction or depletion in order to restore salt balance. Renal salt retention and increased sodium appetite can also be maladaptive and sustain the pathophysiology in conditions like salt-sensitive hypertension and chronic heart failure. Here we review the central role of the mineralocorticoid aldosterone in both the increase in renal salt reabsorption and sodium appetite. We discuss the working hypothesis that aldosterone activates similar signaling and effector mechanisms in the kidney and brain, including the mineralocorticoid receptor, the serum- and glucocorticoid-induced kinase SGK1, the ubiquitin ligase NEDD4-2, and the epithelial sodium channel $\mathrm{ENaC}$. The latter also mediates the gustatory salt sensing in the tongue, which is required for the manifestation of increased salt intake. Effects of aldosterone on both the brain and kidney synergize with the effects of angiotensin II. Thus, mineralocorticoids appear to induce similar mo-
\end{abstract}

\section{KARGER}

E-Mail karger@karger.com

www.karger.com/nep lecular pathways in the kidney, brain, and possibly tongue, which could provide opportunities for more effective therapeutic interventions. Inhibition of renal salt reabsorption is compensated by stimulation of salt appetite and vice versa; targeting both mechanisms should be more effective. Inhibiting the arousal to consume salty food may improve a patient's compliance to reducing salt intake. While a better understanding of the molecular mechanisms is needed and will provide new therapeutic options, current pharmacological interventions that target both salt retention and sodium appetite include mineralocorticoid receptor antagonists and potentially inhibitors of angiotensin II and $\mathrm{ENaC}$.

(c) 2014 S. Karger AG, Basel

\section{Introduction}

Sodium chloride (salt) homeostasis depends on the balance of salt intake and excretion, the latter being primarily mediated by the kidneys. Impaired renal salt excretion combined with excess salt intake can cause arterial hypertension, a leading cause of cardiovascular death [1]. Much has been learned about the molecular mechanisms and genetics that regulate renal salt reabsorption and excretion. The molecular determinants of salt intake,
(C) 2014 S. Karger AG, Basel

$1660-2137 / 14 / 1282-0008 \$ 39.50 / 0$
Dr. Volker Vallon

Division of Nephrology and Hypertension, Departments of Medicine and Pharmacology University of California San Diego and VA San Diego Healthcare System 3350 La Jolla Village Drive (9151), San Diego, CA 92161 (USA)

E-Mail vvallon@ ucsd.edu 
however, are still poorly understood. Salt intake is known to vary significantly from person to person, and, at least in part through its positive association with blood pressure, is a risk factor for non-diabetic chronic kidney disease [2]. In comparison, salt intake has been negatively correlated with renal outcome and mortality in patients with diabetes [3]. These findings underline the need to better understand the determinants of salt intake.

'Sodium appetite', i.e. the preference for salty food and fluid, is one factor that contributes to salt intake. In this review we discuss the regulation of sodium appetite by mineralocorticoids. More specifically, we propose that mineralocorticoid-induced sodium appetite in the brain shares some of the molecular mechanisms that mediate the salt-retaining effect of mineralocorticoids in the kidney. We will first introduce the general phenomenon of sodium appetite [for excellent reviews, see 4,5 ]. We will briefly discuss well-established signaling pathways and effectors involved in renal actions of mineralocorticoids and then explore their roles in sodium appetite. Patients with diseases like congestive heart failure, salt-sensitive hypertension, liver or kidney failure are often non-compliant with regard to the recommendation of eating a lowsodium diet $[6,7]$. This is in part due to the underlying pathophysiology, which may induce sodium appetite [812]. A better understanding of the determinants and molecular mechanisms of sodium appetite may provide new preventive and therapeutic avenues.

\section{Salt Intake and the Phenomenon of Sodium Appetite}

The total volume of extracellular fluid in the body depends largely upon the amount of sodium present in the extracellular space. Normal growth requires the ingestion and retention of sodium. Associated water input and output are adjusted to tightly control osmotic pressure. The Institute of Medicine set the adequate intake for sodium in young adults at $1.5 \mathrm{~g}(65 \mathrm{mmol}) /$ day ( $3.8 \mathrm{~g}$ of salt). Further recommendations include a tolerable upper limit for sodium intake of $2.3 \mathrm{~g}(100 \mathrm{mmol}) /$ day (5.8 g of salt) at $\geq 14$ years (http://www.nal.usda.gov/fnic/DRI/DRI_Water/water_full_report.pdf). Based on the latter recommendation, in $2009-2010$ about $80 \%$ of the US population aged $\geq 1$ year consumed excess sodium with a mean intake of $3.4 \mathrm{~g} /$ day ( $8.5 \mathrm{~g}$ of salt) (http://www.cdc.gov/ $\mathrm{mmwr} /$ preview/mmwrhtml/mm6250a1.htm).

Sodium appetite is a highly motivated behavioral state and hard-wired regulatory mechanism that drives animals $[13,14]$ and humans $[11,15-18]$ to seek and ingest foods and fluids containing sodium. This occurs in conditions of negative salt balance, such as dietary salt deprivation or loss due to excessive sweating, impaired renal sodium retention (Gitelman's syndrome) or impaired aldosterone formation (mutation in $21 \beta$-hydroxylase), as well as after peritoneal dialysis, diarrhea, or diuretic treatment, when it is an essential behavioral mechanism to restore salt balance. In accordance with its importance, sodium-deprived rats choose the taste of sodium over moderate intensities of directly rewarding brain stimulation [19]. Notably, the appetite stimulated by salt deficiency is highly specific for the taste of sodium salts [20] and the paired anion (chloride, acetate, etc.) has little or no effect on this preference [21].

Together with thirst, sodium appetite is critical for restoring extracellular fluid and preserving life. The sodium concentration in the cerebrospinal fluid (CSF) is positively related to its plasma concentration [22], and an increased CSF sodium concentration stimulates thirst [23] and inhibits sodium appetite [24-26]. The latter response involves the sodium sensor, $\mathrm{NaX}$ [27] (fig. 1). $\mathrm{NaX}$ is located in forebrain circumventricular organs [28], a region that lacks a blood-brain barrier, and in many glial cells in the subfornical organ (SFO) and other parts of the lamina terminalis, which makes them uniquely sensitive to large increases in the extracellular sodium concentration [2832]. In mice, $\mathrm{NaX}$ in the SFO is necessary for the rapid stimulation of thirst by hypertonic saline infusion, as well as the inhibition of salt intake after $24 \mathrm{~h}$ water deprivation $[28,31]$. This channel, however, seems unlikely to sense subnormal sodium concentrations or salt depletion. Furthermore, whether a reduction in intracerebroventricular (icv) fluid sodium concentration increases sodium appetite remains unclear. Circumstantial evidence has been published in sheep [24, 25], and a sodium sensor proposed $[25,33,34]$, but the nature of this hypothetical lowsodium sensor remains unknown and the findings could not be confirmed in rabbits, rats, and mice [35-37].

The pioneering work by Curt Richter established the phenomenon of sodium appetite when he studied the responses in rats following removal of the adrenal glands; he further showed that continuous dietary supplementation of sodium is required to prevent death following removal or gross dysfunction of the adrenal glands, and that saline intake returned to normal when functional adrenal tissue was transplanted back $[14,18,20]$. Subsequent studies showed that replacement doses of mineralocorticoids, including aldosterone $[38,39]$, mimicked this effect of retransplantation. These studies introduced a role of mineralocorticoids in the stimulation of sodium appe- 


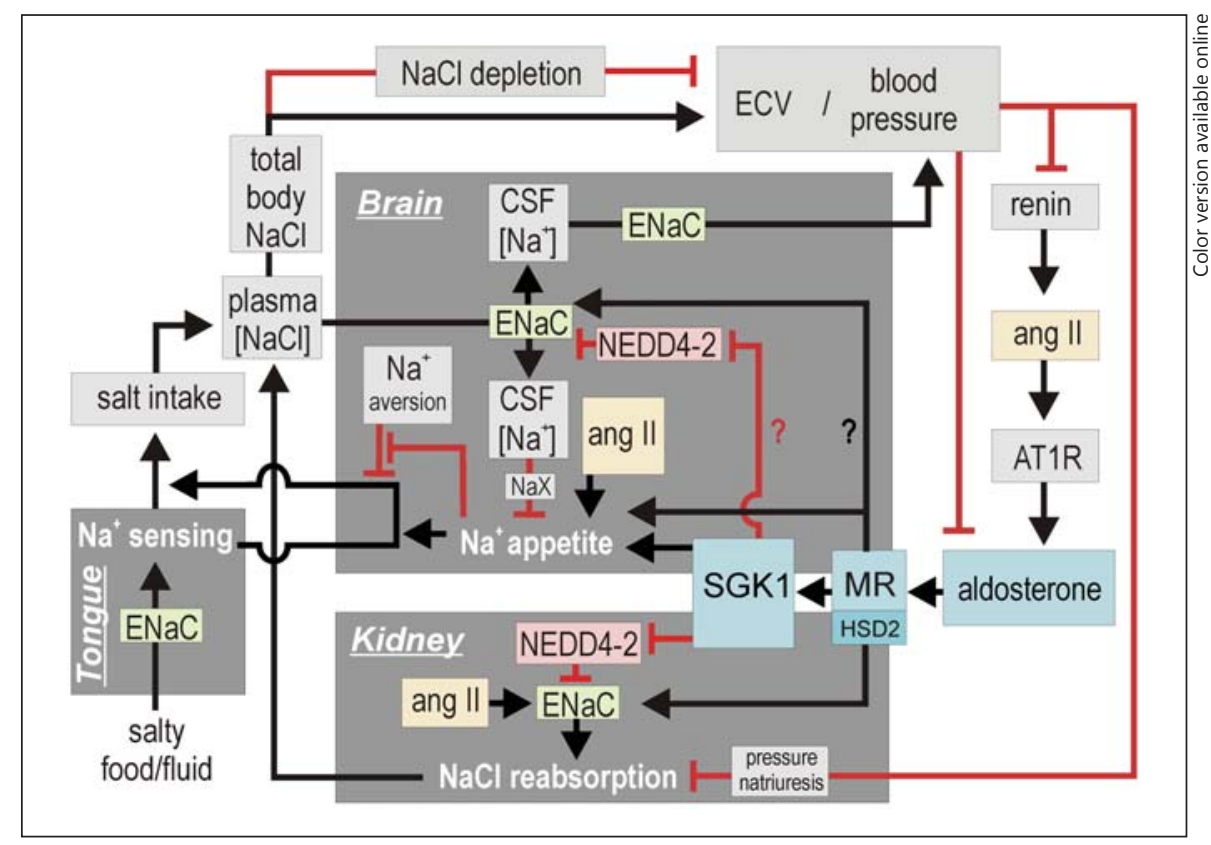

Fig. 1. Proposed central role of the mineralocorticoid aldosterone in salt homeostasis through its effects on both the increase in renal salt reabsorption and sodium appetite. Aldosterone activates similar molecular mechanisms in the kidney and brain, including the MR and the serum- and glucocorticoid-induced kinase SGK1. The ubiquitin ligase NEDD4-2 and the epithelial sodium channel $\mathrm{ENaC}$ have also both been implicated in salt homeostasis in the kidney and brain. ENaC also mediates the gustatory sodium sensing in the tongue, which together with inhibition of sodium aver-

tite. The clinical relevance was further illustrated in a case report by Wilkins and Richter in 1940 that described the severe salt cravings of a boy from a very early age; this boy had undiagnosed corticoadrenal insufficiency and his life, like Richter's adrenalectomized rats, depended on the continuous intake of sodium, and he died after being denied access to salt during hospitalization [18]. Subsequent studies refined the system indicating that angiotensin II, baroreceptors, cerebral osmoreceptors, and other neurohormones modulate the aldosterone-induced arousal of sodium appetite $[4,5]$.

\section{Mineralocorticoids Stimulate Renal Salt Reabsorption}

The strongest stimulator for the secretion of aldosterone from the adrenal gland is salt loss and volume depletion, which occurs independent of circulating angiotensin II levels [40-42], although the latter can also stimulate sion is required for the manifestation of sodium appetite-induced increase in salt intake. Effects of aldosterone on both the brain and kidney synergize with the effects of angiotensin II (ang II). Inhibition of renal salt reabsorption is compensated by stimulation of salt appetite and vice versa. Therefore, inhibiting both mechanisms has advantages. Current pharmacological interventions that target salt retention and appetite include MR antagonists, and potentially inhibitors of Ang II and ENaC. See text for further details. $\mathrm{AT1R}=$ Ang II AT1 receptor; $\mathrm{ECV}$ = effective circulating volume.

aldosterone release (fig. 1). Aldosterone binds to the mineralocorticoid receptor (MR) expressed in a variety of tissues including the distal convoluted tubule, connecting tubule, and collecting duct of the kidney [43-45] to induce salt retention. In more detail, translocation of ligand-bound MR to the nucleus activates gene transcription of multiple genes including the serum and glucocorticoid-induced kinase SGK1, which contributes to enhancing the expression of the $\alpha$-subunit of the basolateral expressed $\mathrm{Na}$, K-ATPase as well as the $\alpha$-subunit of the apical expressed epithelial sodium channel $(\mathrm{ENaC})$ $[46,47]$. Upregulation of ENaC involves SGK1-mediated relief of Dot1a-Af9-mediated transcriptional repression of $\mathrm{ENaCa}$ [48]. Ubiquitination of $\mathrm{ENaC}$ by the ubiquitin ligase, neural precursor cell expressed and developmentally downregulated 4-2 (NEDD4-2), leads to ENaC retrieval from the apical membrane [49]. SGK1 phosphorylates NEDD4-2 and prevents NEDD4-2 to interact with $\mathrm{ENaC}$, thereby enhancing the accumulation of $\mathrm{ENaC}$ at the plasma membrane for maximum activity (fig. 1). Al- 
dosterone can also stimulate the $\mathrm{NaCl}$ co-transporter NCC in the distal convoluted tubule [50] and the $\mathrm{Cl}^{-}$$\mathrm{HCO}_{3}{ }^{-}$exchanger pendrin in intercalated cells [51] to enhance reabsorption of $\mathrm{Cl}^{-}$. This upregulation of NCC likewise involves SGK1 and NEDD4-2 [50, 52].

\section{Mineralocorticoids Stimulate Sodium Appetite}

Adrenalectomy induces renal salt loss and causes rats to drink large amounts of saline to maintain salt balance, implying compensation by aldosterone-independent mechanisms. Substituting low doses of mineralocorticoids in these rats reduced renal salt excretion and saline intake [38, 53-55]; aldosterone levels around $85 \mathrm{pg} / \mathrm{ml}$, which is well within the physiological range, resulted in the lowest saline intake [54]. A higher mineralocorticoid dose increased saline intake in adrenalectomized rats [38, 55]. High doses of the mineralocorticoid desoxycorticosterone acetate (DOCA) or aldosterone also increased saline intake in rats $[38,56,57]$, mice $[58,59]$, and primates [60] with intact adrenal glands. Humans have also demonstrated preference for salt in certain conditions such as following extensive exercise or other causes of enhanced or abnormal aldosterone production $[61,62]$.

\section{MRs in the Brain Mediate Stimulation of Sodium Appetite}

Hypernatremia inhibits salt intake [26, 28, 63, 64] (fig. 1). In comparison, plasma sodium levels are often unaltered during sodium depletion, and hyponatremia is neither necessary nor sufficient for stimulating sodium appetite $[4,5]$ (see also discussion above), indicating that the signal of sodium depletion is transmitted to the brain by other means. MRs are widely expressed in the brain, including the choroid plexus, hippocampus, some hypothalamic nuclei, amygdala, circumventricular organs, brain stem, cerebellum, and cortex [65-67]. Studies in rats showed that chronic infusion of aldosterone into the fourth ventricle increased the daily salt intake [68]. Vice versa, injection of the MR antagonist RU-28318 into the fourth ventricle reduced the sodium appetite following loop diuretic-induced salt depletion [68]. Inhibition of saline intake was also shown by icv application of the MR antagonist spironolactone in an experimental model mimicking microgravity and bed rest [69] as well as in a chronic heart failure model [12]. Daily injection of DOCA directly into the amygdala increased saline intake in rats; this response was significantly inhibited by intracranial application of antisense oligodeoxynucleotides against MR, but not against the glucocorticoid receptor [70]. With regard to the dynamics of the system, direct application of DOCA or aldosterone into the amygdala increased saline intake within $15 \mathrm{~min}$; pretreatment with a MR antagonist $1 \mathrm{~h}$ beforehand inhibited the aldosterone-induced saline intake [70]. Such a rapid response is consistent with the observation that $1 \mathrm{~h}$ of intense exercise increased the salt preference in human [61]. These studies implicated that activation of MR in the brain is critical for salt depletion-induced sodium appetite (fig. 1).

When in animals with salt depletion icv application of RU-28318 was combined with subcutaneous injection of captopril to suppress endogenous angiotensin II, sodium appetite was completely suppressed; in contrast, peripheral MR blockade did not decrease sodium appetite [71]. Intracerebral injection of angiotensin II is more effective on salt intake and magnifies the aldosterone effect; vice versa, the effect of angiotensin II is enhanced by mineralocorticosteroids $[60,72-74]$, indicating a strong synergy between aldosterone and angiotensin II. Thus, sodium appetite may be the result of simultaneous elevations in peripheral aldosterone and angiotensin II produced by the brain's own renin-angiotensin system [72, 75] (fig. 1). Notably and in contrast to angiotensin II, which stimulates water and sodium intake [76], mineralocorticoids stimulate the intake of sodium with little or no effect on water intake $[56,59,77]$, which may facilitate differential regulation of water and sodium intake.

Glucocorticoids can also bind and activate the MR. In physiological conditions, the circulating concentration of active glucocorticoids is 100 - to 1,000 -fold higher than that of aldosterone. To protect the MR from inappropriate activation by glucocorticoids, $11 \beta$-hydroxysteroid dehydrogenase type 2 (HSD2) is locally expressed to inactivate these glucocorticoids [78]. In accordance, a pronounced increase in sodium appetite was reported in a patient with impaired HSD2 function [79]. Expression of HSD2 has been detected in blood vessel walls and in epithelial cells of the distal nephron, collecting duct, colon, and sweat glands, i.e. in organs of high aldosterone sensitivity. HSD2 expression has been detected in the brain of rats and mice including the nucleus tractus solitarius (NTS) [80-82]. Potential candidates for mediating the induction of sodium appetite include the neurons in the NTS that co-express MR and HSD2 (fig. 1) and are activated (increase in nuclear c-Fos) by chronic salt deprivation and inactivated following salt repletion [83]. These neurons, like sodium appetite, can still be activated by 
dietary sodium deprivation after adrenalectomy, indicating that they integrate other signals in addition to aldosterone [84]. In addition to aldosterone and angiotensin II, multiple endogenous neuromodulators have been implicated in the regulation of sodium appetite but their relevance has not been unequivocally established $[4,5]$.

\section{SGK1 Mediates Mineralocorticoid-Induced Salt Appetite}

SGK1 is induced by serum and glucocorticoids as well as many other stimuli including aldosterone and changes in cell volume [for review, see 47]. It is expressed and induced by mineralocorticoids in a variety of tissues including the kidney, colon, and heart [47]. In human brain, Northern blot analysis showed SGK1 to be expressed in amygdala, caudate nucleus, corpus callosum, hippocampus, substantia nigra, subthalamic nucleus, and thalamus [85]. Cerebral SGK1 is upregulated by glucocorticoids and corticotropin-releasing hormone, and its function has been linked to pathophysiological changes in the central nervous system [86]. Notably, the expression of SGK1 in the choroid plexus of stroke-prone spontaneously hypertensive rats was upregulated by a high-salt diet and this response was attenuated by icv infusion of the MR antagonist eplerenone [87], indicating MR-induced SGK1 in the choroid plexus (fig. 1).

SGK1 mediates DOCA-induced sodium appetite [59]. When given the choice of drinking tap water or $1 \%$ saline, subcutaneous implantation of a DOCA-releasing pellet significantly increased drinking of saline versus tap water in wild-type (WT) mice, consistent with DOCA-induced sodium appetite. This response was reduced or prevented in SGK1 knockout (-/-) mice [59]. In accordance, the preference of pregnant mice to drink a $\mathrm{NaCl}$ solution was reduced when SGK1 was deleted despite of higher plasma aldosterone concentrations compared with WT mice [88].

\section{Is Brain ENaC Involved in Mineralocorticoid-Induced Sodium Appetite?}

In the brain of humans and monkeys, ENAC $\delta$ is the predominantly expressed subunit [89]; in mouse and rat, however, the $\delta$-subunit appears to be a pseudogene and the other three subunits $\alpha, \beta$ and $\gamma$ are predominant. In rat brain, co-expression of $\mathrm{ENaC} \alpha, \beta$ and $\gamma$ have been detected in the cardiovascular regulatory centers includ- ing the magnocellular neurons (MNCs) in the supraoptic nucleus (SON) and the paraventricular nucleus (PVN), in the median preoptic nucleus (MnPO), cingular and piriform cortex, and the hippocampus [67]. The study of adjacent sections suggested that all three $\mathrm{ENaC}$ subunits were co-expressed with MR in the same groups of cells in these regions. In areas such as the SFO, immunoreactivity was prominent only for the $\alpha$ - and $\beta$-subunits of $\mathrm{ENaC}$ and MR whereas $\gamma$-ENaC was not detected; immunoreactivity for $\alpha$ - and $\beta$-ENaC subunits in these regions usually paralleled MR positivity, and co-localized well with neuron marker-positive cells [67]. The three ENaC subunits and MR were also co-localized in vasopressin and oxytocin-positive cells in the SON and PVN in rats [90]. Single cell PCR confirmed mRNA co-expression of all three $\mathrm{ENaC}$ subunits and MR in MNCs from those areas, and, by using the $\mathrm{ENaC}$ blocker benzamil, indirect evidence was provided that ENaCs can affect the firing patterns of MNCs [90]. Studies in mice confirmed the expression of all three $\mathrm{ENaC}$ subunits in cortex, choroid plexus, SFO, SON, and PVN [91]. Thus, where studied, co-expression of ENaC subunits and MR has been regularly confirmed in the central nervous system, a prerequisite for the regulation of $\mathrm{ENaC}$ by aldosterone (fig. 1).

As introduced above, $\mathrm{ENaC}$ is ubiquitinated by NEDD4-2, which marks ENaC for internalization in the kidney. In accordance, Nedd4-2 $2^{-/}$mice have increased plasma membrane expression of $\mathrm{ENaC}$ subunits in the distal nephron and collecting duct [92]. Notably, Leenen's group described that these mice also have increased expression of $\mathrm{ENaC}$ subunits in the cytoplasm and plasma membranes in the central nervous system including neurons and the choroid plexus [91] (fig. 1). Moreover, acute icv infusion of sodium-rich CSF increased arterial blood pressure by around $10 \mathrm{~mm} \mathrm{Hg}$ in WT mice, while in Nedd4-2 $2^{-/-}$mice, the blood pressure increased by $25-$ $30 \mathrm{~mm} \mathrm{Hg}$ (fig. 1). This enhancement was abolished by icv infusion of the $\mathrm{ENaC}$ inhibitor, benzamil [91]. The group further found that a high-salt diet increased the sodium concentrations in CSF in Nedd $4-2^{-/-}$but not in WT mice. Finally, the high-salt diet increased mean blood pressure by $30-35 \mathrm{~mm} \mathrm{Hg}$ in Nedd $4-2^{-/-}$mice, a response largely prevented by icv benzamil but only to a minor extent by subcutaneous benzamil at the icv rate [91]. Leenen and co-workers concluded that increased $\mathrm{ENaC}$ expression in the brain of Nedd4- $2^{-/-}$mice mediates their hypertensive response to a high-salt diet by increasing sodium concentrations in the CSF, as well as hyperresponsiveness to CSF sodium (fig. 1). Similarly, chronic icv infusion of benzamil abolished the sympathetic hyperactiv-
$\mathrm{Fu} /$ Vallon 
ity and hypertension caused by chronic icv infusion of sodium-rich CSF or by high-salt diet in Dahl salt-sensitive $(S)$ rats [93]. Dahl $S$ also exhibited an increase in CSF sodium concentration in response to a high-salt diet [94], as well as enhanced sympathoexcitatory and pressor responses to increasing sodium concentration in CSF [95], thus mimicking the phenotype of Nedd $4-2^{-/-}$mice. Together these findings suggest a possible role of $\mathrm{ENaC}$ in sodium regulation in brain and in the etiology of high-salt diet-induced hypertension. Further studies are needed, however, to more specifically test the role of brain $\mathrm{ENaC}$ in this regard and for mineralocorticoid-induced salt appetite. Dietary sodium inhibits the open probability of $\mathrm{ENaC}$ in the kidney by enhancing apical ATP/UTP release and P2Y2 receptor activation [96]. Mice lacking this receptor present DOCA-induced salt-sensitive hypertension associated with salt aversion when given access to tap water and $1 \% \mathrm{NaCl}$ solution [96]. It remains to be determined whether the ATP/UTP/P2Y2 receptor system regulates brain $\mathrm{ENaC}$ and $\mathrm{CSF}$ sodium concentrations.

\section{Sensing of Salty Food and Fluid via $\mathrm{ENaC}$ in the Tongue}

Sodium-deficient rats cannot discriminate saline from other solutions when gustatory sodium channels were blocked [97-99]. ENaC is expressed in the gustatory system where it contributes to salt sensing during salt deprivation. Conditional knockdown of $\mathrm{ENaCa}$ in all taste receptor cells of the tongue prevented amiloride-sensitive sodium uptake in the low $\mathrm{NaCl}$ concentration range, while these animals retained the normal responses to non-sodium salts [100]. Furthermore, whereas diureticinduced sodium depletion induced sodium appetite in WT, mice with $\mathrm{ENaCa}$ knockdown in the tongue showed little or no preference for $\mathrm{NaCl}$ solutions relative to water [100]. These studies indicated that salt depletion-induced sodium appetite uses $\mathrm{ENaC}$-mediated $\mathrm{Na}^{+}$uptake in tongue epithelia to identify dietary salt sources (fig. 1). To our knowledge, the expression of MR, SGK1, or NEDD42 in tongue or the effects of aldosterone or angiotensin II on $\mathrm{ENaC}$ have not been studied.

Geerling and Loewy $[4,83,101]$ have proposed a model with three central components to explain the induction of sodium appetite following salt depletion. First, during salt depletion, specific groups of neurons (see candidates in NTS above) provide signals for sodium need that motivate salt-seeking behavior. Second, once sodium is tasted (see above), the gustatory apparatus transmits a signal representing sodium detection. Third, these two signals are integrated (along with inhibitory signals that promote sodium aversion) in one or more forebrain sites (possibly including the nucleus accumbens and a dopamine-dependent motivational signal for salt intake) that ultimately drive motivated ingestive behavior (fig. 1).

\section{Summary and Perspectives}

The body responds to salt restriction or depletion with an increase in renal salt retention and an increase in sodium appetite to restore salt balance. Both mechanisms involve the mineralocorticoid, aldosterone. By activation of the MR in the aldosterone-sensitive distal nephron, aldosterone induces early transcriptional upregulation of SGK1 expression. SGK1 stimulates basolateral $\mathrm{Na}, \mathrm{K}-$ ATPase, increases the expression of $\mathrm{ENaC}$, and suppresses the activity of the ubiquitin ligase NEDD4-2 to retain $\mathrm{ENaC}$ in the luminal membrane and maximize $\mathrm{ENaC} \mathrm{ac}-$ tivity and sodium reabsorption. The induction of sodium appetite by aldosterone in the brain involves a similar molecular pattern. A role for the MR and SGK1 in mineralocorticoid-induced sodium appetite has been established. The aldosterone sensitivity, sodium appetite-associated activation and input/output connections of neurons that co-express the MR and HSD2 implicated these neurons in the NTS in the induction of sodium appetite. NEDD4-2 has been implicated in the regulation of $\mathrm{ENaC}$ in brain thereby affecting sodium concentrations in CSF and blood pressure. Effects of aldosterone on both brain and kidney synergize with the effects of angiotensin II. The induction of salt intake also relies on gustatory saltsensing mechanisms in the tongue that involve $\mathrm{ENaC}$ in taste buds.

Thus, mechanisms that regulate salt homeostasis via effects on the kidney, brain, and tongue share some of the molecular pathways, yet many issues need further clarification. It remains to be determined whether aldosterone regulates $\mathrm{ENaC}$ in brain and whether this contributes to sodium appetite. How does brain $\mathrm{ENaC}$ affect the sodium concentration in CSF, and does $\mathrm{ENaC}$ mediate effects of increased CSF sodium on blood pressure? We need to better understand how aldosterone influences these unique neurons at the cellular and local-circuit levels. Does aldosterone (via MR activation) or angiotensin II affect $\mathrm{ENaC}$ in the tongue and what are the downstream signaling cascades of ENaC-mediated sodium sensing? More data are needed regarding the regulation of sodium appetite in humans and its relevance in various disease states. 
Common molecular pathways may provide the opportunity for more effective therapeutic intervention. In other words, a drug targeting a molecule common to both pathways allows to inhibit renal salt retention and sodium appetite at the same time. Inhibition of renal salt reabsorption is compensated by stimulation of sodium appetite and vice versa. Therefore, inhibiting both mechanisms should be more effective. Inhibiting the arousal to consume salty food or fluid may improve a patient's compliance to reducing salt intake. This may be relevant in patients with salt-sensitive hypertension or chronic heart failure, and animal models provided first evidence for salt appetite under these conditions $[9,12]$. Potential candidates for pharmacological interventions that can inhibit both renal sodium retention and sodium appetite include drugs that have been shown to provide long-term health benefits in patients, such as MR antagonists or inhibitors of angiotensin II, and their combination could be par- ticularly effective in this regard. Additional candidates include inhibitors of ENaC. A better understanding of the molecular mechanisms is needed, which holds the potential for new therapeutic approaches.

\section{Acknowledgements}

This work was supported by NIH grants R01DK56248 and R01HL94728, the UAB/UCSD O'Brien Center of Acute Kidney Injury NIH-P30DK079337, and the Department of Veterans Affairs (all to V.V.).

\section{Disclosure Statement}

Within the past 12 months, Dr. Vallon has received research grant support for basic science studies from Boehringer Ingelheim Pharma GmbH \& Co. KG and Amylin/Bristol-Myers Squibb.

\section{References}

1 Roger VL, Go AS, Lloyd-Jones DM, Benjamin EJ, Berry JD, Borden WB, Bravata DM, Dai S, Ford ES, Fox CS, Fullerton HJ, Gillespie C, Hailpern SM, Heit JA, Howard VJ, Kissela BM, Kittner SJ, Lackland DT, Lichtman JH, Lisabeth LD, Makuc DM, Marcus GM, Marelli A, Matchar DB, Moy CS, Mozaffarian D, Mussolino ME, Nichol G, Paynter NP, Soliman EZ, Sorlie PD, Sotoodehnia N, Turan TN, Virani SS, Wong ND, Woo D, Turner MB: Heart disease and stroke statistics - 2012 update: a report from the American Heart Association. Circulation 2012;125:e2-e220.

2 Anderson CA, Ix JH: Sodium reduction in CKD: suggestively hazardous or intuitively advantageous? J Am Soc Nephrol 2013;24: 1931-1933.

-3 Vallon V, Thomson SC: Anomalous role for dietary salt in diabetes mellitus? Nat Rev Endocrinol 2011;7:377-378.

-4 Geerling JC, Loewy AD: Central regulation of sodium appetite. Exp Physiol 2008;93:177209.

5 Krause EG, Sakai RR: Richter and sodium appetite: from adrenalectomy to molecular biology. Appetite 2007;49:353-367.

6 Korhonen MH, Litmanen H, Rauramaa R, Vaisanen SB, Niskanen L, Uusitupa M: Adherence to the salt restriction diet among people with mildly elevated blood pressure. Eur J Clin Nutr 1999;53:880-885.

-7 Ohta Y, Tsuchihashi T, Ueno M, Kajioka T, Onaka U, Tominaga M, Eto K: Relationship between the awareness of salt restriction and the actual salt intake in hypertensive patients. Hypertens Res 2004;27:243-246.
8 Langford HG, Watson RL, Thomas JG: Salt intake and the treatment of hypertension. Am Heart J 1977;93:531-532.

-9 DiNicolantonio R, Hutchinson JS, Mendelsohn FA: Exaggerated salt appetite of spontaneously hypertensive rats is decreased by central angiotensin-converting enzyme blockade. Nature 1982;298:846-848.

$\checkmark 10$ Hurley RS, Hebert LA, Rypien AB: A comparison of taste acuity for salt in renal patients vs. normal subjects. J Am Diet Assoc 1987;87: 1531-1534.

11 Leshem M, Rudoy J: Hemodialysis increases the preference for salt in soup. Physiol Behav 1997;61:65-69.

12 Francis J, Weiss RM, Wei SG, Johnson AK, Beltz TG, Zimmerman K, Felder RB: Central mineralocorticoid receptor blockade improves volume regulation and reduces sym pathetic drive in heart failure. Am J Physiol Heart Circ Physiol 2001;281:H2241-H2251.

13 Denton DA, Blair-West JR, McBurnie M, Osborne PG, Tarjan E, Williams RM, Weisinger RS: Angiotensin and salt appetite of BALB/C mice. Am J Physiol 1990;259:R729-R735.

14 Richter CP: Increased salt appetite in adrenalectomized rats. Am J Physiol 1936;115:155161.

15 Takamata A, Mack GW, Gillen CM, Nadel ER: Sodium appetite, thirst, and body fluid regulation in humans during rehydration without sodium replacement. Am J Physiol 1994;266:R1493-R1502.
16 Cruz DN, Simon DB, Nelson-Williams C, Farhi A, Finberg K, Burleson L, Gill JR, Lifton RP: Mutations in the $\mathrm{NaCl}$ cotransporter reduce blood pressure in humans. Hypertension 2001;37:1458-1464.

17 Kochli A, Tenenbaum-Rakover Y, Leshem M: Increased salt appetite in patients with congenital adrenal hyperplasia 21-hydroxylase deficiency. Am J Physiol Regul Integr Comp Physiol 2005;288:R1673-R1681.

18 Wilkins L, Richter CP: A great craving for salt by a child with cortico-adrenal insufficiency. JAMA 1940;114:866-868.

19 Conover KL, Woodside B, Shizgal P: Effects of sodium depletion on competition and summation between rewarding effects of salt and lateral hypothalamic stimulation in the rat. Behav Neurosci 1994;108:549-558.

20 Richter CP, Eckert JF: Mineral metabolism of adrenalectomized rats studied by the appetite method. Endocrinology 1938;22:214-224.

21 Nachman M: Taste preferences for sodium salts by adrenalectomized rats. J Comp Physiol Psychol 1962;55:1124-1129.

22 Doi Y, Nose H, Morimoto T: Changes in Na concentration in cerebrospinal fluid during acute hypernatremia and their effect on drinking in juvenile rats. Physiol Behav 1992; 52:499-504.

23 Andersson B: Regulation of water intake. Physiol Rev 1978;58:582.

24 Weisinger RS, Considine P, Denton DA, McKinley MJ: Rapid effect of change in cerebrospinal fluid sodium concentration on salt appetite. Nature 1979;280:490-491. 
-25 Weisinger RS, Considine P, Denton DA, Leksell L, McKinley MJ, Mouw DR, Muller AF, Tarjan E: Role of sodium concentration of the cerebrospinal fluid in the salt appetite of sheep. Am J Physiol 1982;242:R51-R63.

26 Chiaraviglio E, Perez Guaita MF: The effect of intracerebroventricular hypertonic infusion on sodium appetite in rats after peritoneal dialysis. Physiol Behav 1986;37:695-699.

27 Noda M: The subfornical organ, a specialized sodium channel, and the sensing of sodium levels in the brain. Neuroscientist 2006;12: $80-91$.

28 Watanabe E, Fujikawa A, Matsunaga H, Yasoshima Y, Sako N, Yamamoto T, Saegusa C, Noda M: Nav2/NaG channel is involved in control of salt-intake behavior in the CNS. J Neurosci 2000;20:7743-7751.

-29 Watanabe E, Hiyama TY, Shimizu H, Kodama R, Hayashi N, Miyata S, Yanagawa Y, Obata K, Noda M: Sodium-level-sensitive sodium channel $\mathrm{Na}(\mathrm{x})$ is expressed in glial laminate processes in the sensory circumventricular organs. Am J Physiol Regul Integr Comp Physiol 2006;290:R568-R576.

-30 Hiyama TY, Watanabe E, Ono K, Inenaga K, Tamkun MM, Yoshida S, Noda M: $\mathrm{Na}(\mathrm{x})$ channel involved in CNS sodium-level sensing. Nat Neurosci 2002;5:511-512.

- 31 Hiyama TY, Watanabe E, Okado H, Noda M: The subfornical organ is the primary locus of sodium-level sensing by $\mathrm{Na}(\mathrm{x})$ sodium channels for the control of salt-intake behavior. J Neurosci 2004;24:9276-9281.

- 32 Grob M, Drolet G, Mouginot D: Specific $\mathrm{Na}^{+}$ sensors are functionally expressed in a neuronal population of the median preoptic nucleus of the rat. J Neurosci 2004;24:3974-3984.

- 33 Weisinger RS, Denton DA, McKinley MJ, Muller AF, Tarjan E: Cerebrospinal fluid sodium concentration and salt appetite. Brain Res 1985;326:95-105.

-34 Denton DA, McKinley MJ, Weisinger RS: Hypothalamic integration of body fluid regulation. Proc Natl Acad Sci USA 1996;93:73977404.

35 Denton DA, McKinley MJ, Nelson JF, Osborne P, Simpson J, Tarjan E, Weisinger RS: Species differences in the effect of decreased CSF sodium concentration on salt appetite. J Physiol (Paris) 1984;79:499-504.

-36 Frankmann SP, Sakai RR, Simpson JB: Sodium appetite and cerebrospinal fluid sodium concentration during hypovolemia. Appetite 1987;9:57-64.

37 Osborne PG, Blair-West JR, Denton DA, McBurnie M, Tarjan E, Williams RM, Weisinger RS: Decreased cerebral sodium concentration and sodium appetite in BALB/c mice. Am J Physiol 1990;259:R741-R744.

38 Wolf G: Effect of deoxycorticosterone on sodium appetite of intact and adrenalectomized rats. Am J Physiol 1965;208:1281-1285.

39 Fregly MJ, Waters IW: Effect of spironolactone on spontaneous $\mathrm{NaCl}$ intake of adrenalectomized rats. Proc Soc Exp Biol Med 1966; 123:971-975.
40 Okubo S, Niimura F, Nishimura H, Takemoto F, Fogo A, Matsusaka T, Ichikawa I: Angiotensin-independent mechanism for aldosterone synthesis during chronic extracellular fluid volume depletion. J Clin Invest 1997;99: 855-860.

41 Makhanova N, Sequeira-Lopez ML, Gomez RA, Kim HS, Smithies O: Disturbed homeostasis in sodium-restricted mice heterozygous and homozygous for aldosterone synthase gene disruption. Hypertension 2006; 48: 1151-1159.

42 Bojensen E: Concentration of aldosterone and corticosterone in peripheral plasma of rats. The effects of salt depletion, salt repletion, potassium loading and intravenous injection of renin and angiotensin II. Eur J Steroids 1966;1:145-169.

43 Thomas CP, Itani OA: New insights into epithelial sodium channel function in the kidney: site of action, regulation by ubiquitin ligases, serum- and glucocorticoid-inducible kinase and proteolysis. Curr Opin Nephrol Hypertens 2004;13:541-548.

44 Vandewalle A, Farman N, Bencsath P, Bonvalet JP: Aldosterone binding along the rabbit nephron: an autoradiographic study on isolated tubules. Am J Physiol 1981;240:F172F179.

45 Lombes M, Farman N, Oblin ME, Baulieu EE, Bonvalet JP, Erlanger BF, Gasc JM: Immunohistochemical localization of renal mineralocorticoid receptor by using an anti-idiotypic antibody that is an internal image of aldosterone. Proc Natl Acad Sci USA 1990;87:10861088.

-46 Soundararajan R, Lu M, Pearce D: Organization of the ENaC-regulatory machinery. Crit Rev Biochem Mol Biol 2012;47:349-359.

47 Lang F, Bohmer C, Palmada M, Seebohm G, Strutz-Seebohm N, Vallon V: (Patho)physiological significance of the serum- and glucocorticoid-inducible kinase isoforms. Physiol Rev 2006;86:1151-1178.

48 Zhang W, Xia X, Reisenauer MR, Rieg T, Lang F, Kuhl D, Vallon V, Kone BC: Aldosteroneinduced Sgk1 relieves Dotla-Af9-mediated transcriptional repression of epithelial $\mathrm{Na}^{+}$ channel $\alpha$. J Clin Invest 2007;117:773-783.

49 Rotin D, Staub O: Role of the ubiquitin system in regulating ion transport. Pflugers Arch 2011;461:1-21.

50 Arroyo JP, Lagnaz D, Ronzaud C, Vazquez N, Ko BS, Moddes L, Ruffieux-Daidie D, Hausel P, Koesters R, Yang B, Stokes JB, Hoover RS, Gamba G, Staub O: Nedd4-2 modulates renal $\mathrm{Na}^{+}-\mathrm{Cl}^{-}$cotransporter via the aldosteroneSGK1-Nedd4-2 pathway. J Am Soc Nephrol 2011;22:1707-1719.

51 Wall SM, Weinstein AM: Cortical distal nephron $\mathrm{Cl}^{-}$transport in volume homeostasis and blood pressure regulation. Am J Physiol Renal Physiol 2013;305:F427-F438.
52 Vallon V, Schroth J, Lang F, Kuhl D, Uchida S: Expression and phosphorylation of the $\mathrm{Na}^{+}-\mathrm{Cl}^{-}$cotransporter NCC in vivo is regulated by dietary salt, potassium, and SGK1. Am J Physiol Renal Physiol 2009;297:F704F712.

53 McEwen BS, Lambdin LT, Rainbow TC, De Nicola AF: Aldosterone effects on salt appetite in adrenalectomized rats. Neuroendocrinology 1986;43:38-43.

54 Tordoff MG, Hughes RL, Pilchak DM: Different effects of three aldosterone treatments on plasma aldosterone and salt intake. Physiol Behav 1993;54:129-134.

55 Fregly MJ, Waters IW: Effect of mineralocorticoids on spontaneous sodium chloride appetite of adrenalectomized rats. Physiol Behav 1966;1:65-74.

56 Geerling JC, Loewy AD: Aldosterone-sensitive NTS neurons are inhibited by saline ingestion during chronic mineralocorticoid treatment. Brain Res 2006;1115:54-64.

57 Weisinger RS, Woods SC: Aldosterone-elicited sodium appetite. Endocrinology 1971;89: 538-544.

58 Blair-West JR, Denton DA, McBurnie M, Tarjan E, Weisinger RS: Influence of adrenal steroid hormones on sodium appetite of BALB/c mice. Appetite 1995;24:11-24.

59 Vallon V, Huang DY, Grahammer F, Wyatt AW, Osswald H, Wulff P, Kuhl D, Lang F: SGK1 as a determinant of kidney function and salt intake in response to mineralocorticoid excess. Am J Physiol Regul Integr Comp Physiol 2005;289:R395-R401.

-60 Shade RE, Blair-West JR, Carey KD, Madden LJ, Weisinger RS, Denton DA: Synergy between angiotensin and aldosterone in evoking sodium appetite in baboons. Am J Physiol Regul Integr Comp Physiol 2002;283:R1070R1078.

61 Leshem M, Abutbul A, Eilon R: Exercise increases the preference for salt in humans. Appetite 1999;32:251-260.

62 Pimenta E, Gordon RD, Stowasser M: Salt, aldosterone and hypertension. J Hum Hypertens 2013;27:1-6

63 Weisinger RS, Denton DA, McKinley MJ: Self-administered intravenous infusion of hypertonic solutions and sodium appetite of sheep. Behav Neurosci 1983;97:433-444.

64 Blackburn RE, Samson WK, Fulton RJ, Stricker EM, Verbalis JG: Central oxytocin and ANP receptors mediate osmotic inhibition of salt appetite in rats. Am J Physiol 1995;269: R245-R251.

65 Ahima R, Krozowski Z, Harlan R: Type I corticosteroid receptor-like immunoreactivity in the rat CNS: distribution and regulation by corticosteroids. J Comp Neurol 1991;313: 522-538.

66 Gomez-Sanchez CE, de Rodriguez AF, Romero DG, Estess J, Warden MP, Gomez-Sanchez MT, Gomez-Sanchez EP: Development of a panel of monoclonal antibodies against the mineralocorticoid receptor. Endocrinology 2006;147:1343-1348.
Mineralocorticoid-Induced Sodium

Appetite and Renal Salt Retention
Nephron Physiol 2014;128:8-16 DOI: $10.1159 / 000368264$ 
67 Amin MS, Wang HW, Reza E, Whitman SC, Tuana BS, Leenen FH: Distribution of epithelial sodium channels and mineralocorticoid receptors in cardiovascular regulatory centers in rat brain. Am J Physiol Regul Integr Comp Physiol 2005;289:R1787-R1797.

68 Formenti S, Bassi M, Nakamura NB, Schoorlemmer GH, Menani JV, Colombari E: Hindbrain mineralocorticoid mechanisms on sodium appetite. Am J Physiol Regul Integr Comp Physiol 2013;304:R252-R259.

-69 Sullivan MJ, Hasser EM, Moffitt JA, Bruno SB, Cunningham JT: Rats exhibit aldosterone-dependent sodium appetite during $24 \mathrm{~h}$ hindlimb unloading. J Physiol 2004;557:661670.

-70 Sakai RR, McEwen BS, Fluharty SJ, Ma LY: The amygdala: site of genomic and nongenomic arousal of aldosterone-induced sodium intake. Kidney Int 2000;57:1337-1345.

71 Sakai RR, Nicolaidis S, Epstein AN: Salt appetite is suppressed by interference with angiotensin II and aldosterone. Am J Physiol 1986;251:R762-R768.

-72 Fluharty SJ, Epstein AN: Sodium appetite elicited by intracerebroventricular infusion of angiotensin II in the rat. II. Synergistic interaction with systemic mineralocorticoids. Behav Neurosci 1983;97:746-758.

73 Zhang DM, Stellar E, Epstein AN: Together intracranial angiotensin and systemic mineralocorticoid produce avidity for salt in the rat. Physiol Behav 1984;32:677-681.

74 Massi M, Epstein AN: Angiotensin/aldosterone synergy governs the salt appetite of the pigeon. Appetite 1990;14:181-192.

-75 Epstein AN: Mineralocorticoids and cerebral angiotensin may act together to produce sodium appetite. Peptides 1982;3:493-494.

-76 Daniels D, Yee DK, Faulconbridge LF, Fluharty SJ: Divergent behavioral roles of angiotensin receptor intracellular signaling cascades. Endocrinology 2005;146:5552-5560.

77 Wolf G, McGovern JF, Dicara LV: Sodium appetite: Some conceptual and methodologic aspects of a model drive system. Behav Biol 1974;10:27-42.

78 Yang J, Young MJ: The mineralocorticoid receptor and its coregulators. J Mol Endocrinol 2009;43:53-64.

79 Ingram MC, Wallace AM, Collier A, Fraser R, Connell JM: Sodium status, corticosteroid metabolism and blood pressure in normal human subjects and in a patient with abnormal salt appetite. Clin Exp Pharmacol Physiol 1996;23:375-378.
80 Roland BL, Li KX, Funder JW: Hybridization histochemical localization of $11 \beta$-hydroxysteroid dehydrogenase type 2 in rat brain. Endocrinology 1995;136:4697-4700.

81 Robson AC, Leckie CM, Seckl JR, Holmes MC: $11 \beta$-Hydroxysteroid dehydrogenase type 2 in the postnatal and adult rat brain. Brain Res Mol Brain Res 1998;61:1-10.

82 Holmes MC, Sangra M, French KL, Whittle IR, Paterson J, Mullins JJ, Seckl JR: 11 $\beta$ Hydroxysteroid dehydrogenase type 2 protects the neonatal cerebellum from deleterious effects of glucocorticoids. Neuroscience 2006; 137:865-873.

83 Geerling JC, Loewy AD: Aldosterone in the brain. Am J Physiol Renal Physiol 2009; 297:F559-F576.

84 Geerling JC, Engeland WC, Kawata M, Loewy $\mathrm{AD}$ : Aldosterone target neurons in the nucleus tractus solitarius drive sodium appetite. J Neurosci 2006;26:411-417.

85 Warntges S, Friedrich B, Henke G, Duranton C, Lang PA, Waldegger S, Meyermann R, Kuhl D, Speckmann EJ, Obermuller N, Witzgall R, Mack AF, Wagner HJ, Wagner A, Broer S, Lang F: Cerebral localization and regulation of the cell volume-sensitive serumand glucocorticoid-dependent kinase SGK1. Pflugers Arch 2002;443:617-624.

86 Lang F, Strutz-Seebohm N, Seebohm G, Lang UE: Significance of SGK1 in the regulation of neuronal function. J Physiol 2010;588:33493354 .

87 Nakano M, Hirooka Y, Matsukawa R, Ito K, Sunagawa K: Mineralocorticoid receptors/ epithelial $\mathrm{Na}^{+}$channels in the choroid plexus are involved in hypertensive mechanisms in stroke-prone spontaneously hypertensive rats. Hypertens Res 2013;36:277-284.

88 Umbach AT, Pathare G, Foller M, Brosens JJ, Artunc F, Lang F: SGK1-dependent salt appetite in pregnant mice. Acta Physiol (Oxf) 2011;202:39-45.

89 Giraldez T, Rojas P, Jou J, Flores C, Alvarez de la Rosa D: The epithelial sodium channel $\delta$-subunit: new notes for an old song. Am J Physiol Renal Physiol 2012;303:F328-F338.

90 Teruyama R, Sakuraba M, Wilson LL, Wandrey NE, Armstrong WE: Epithelial $\mathrm{Na}^{+}$sodium channels in magnocellular cells of the rat supraoptic and paraventricular nuclei. Am J Physiol Endocrinol Metab 2012;302:E273E285.
-91 Van Huysse JW, Amin MS, Yang B, Leenen $\mathrm{FH}$ : Salt-induced hypertension in a mouse model of Liddle syndrome is mediated by epithelial sodium channels in the brain. Hypertension 2012;60:691-696.

$\checkmark 92$ Shi PP, Cao XR, Sweezer EM, Kinney TS, Williams NR, Husted RF, Nair R, Weiss RM, Williamson RA, Sigmund CD, Snyder PM, Staub O, Stokes JB, Yang B: Salt-sensitive hypertension and cardiac hypertrophy in mice deficient in the ubiquitin ligase Nedd4-2. Am J Physiol Renal Physiol 2008; 295:F462-F470.

93 Wang H, Leenen FH: Brain sodium channels mediate increases in brain 'ouabain' and blood pressure in Dahl S rats. Hypertension 2002;40:96-100.

94 Huang BS, Van Vliet BN, Leenen FH: Increases in CSF $\left[\mathrm{Na}^{+}\right]$precede the increases in blood pressure in Dahl S rats and SHR on a high-salt diet. Am J Physiol Heart Circ Physiol 2004;287:H1160-H1166.

-95 Huang BS, Wang H, Leenen FH: Enhanced sympathoexcitatory and pressor responses to central $\mathrm{Na}^{+}$in Dahl salt-sensitive versus -resistant rats. Am J Physiol Heart Circ Physiol 2001;281:H1881-H1889.

96 Pochynyuk O, Rieg T, Bugaj V, Schroth J, Fridman A, Boss GR, Insel PA, Stockand JD, Vallon V: Dietary $\mathrm{Na}^{+}$inhibits the open probability of the epithelial sodium channel in the kidney by enhancing apical P2Y2-receptor tone. FASEB J 2010;24:2056-2065.

-97 Bernstein IL, Hennessy CJ: Amiloride-sensitive sodium channels and expression of sodium appetite in rats. Am J Physiol 1987; 253:R371-R374.

-98 McCutcheon NB: Sodium-deficient rats are unmotivated by sodium chloride solutions mixed with the sodium channel blocker amiloride. Behav Neurosci 1991;105:764766.

99 Roitman MF, Bernstein IL: Amiloride-sensitive sodium signals and salt appetite: multiple gustatory pathways. Am J Physiol 1999; 276:R1732-R1738.

100 Chandrashekar J, Kuhn C, Oka Y, Yarmolinsky DA, Hummler E, Ryba NJ, Zuker CS: The cells and peripheral representation of sodium taste in mice. Nature 2010;464:297301.

101 Geerling JC, Loewy AD: Aldosterone-sensitive neurons in the nucleus of the solitary tract: efferent projections. J Comp Neurol 2006;497:223-250. 